\title{
Criminalidade, resistência escrava e abolicionismo na Colônia Leopoldina, Bahia (1880-1888)
}

\section{Crime, slave resistance and abolitionism in the Leopoldina Colony, Bahia (1880-1888)}

Ricardo Tadeu Caires Silva*

\begin{abstract}
Resumo
Este artigo tem por objetivo discutir a relação entre a criminalidade escrava e derrocada da escravidão na Colônia Leopoldina, localizada ao sul da província Bahia, no período compreendido entre 1880-1888. Inicialmente concebida para ser uma colônia de imigrantes estrangeiros, composta por pequenos núcleos familiares, a localidade logo se transformou num empreendimento voltado para a agricultura agroexportadora com base no trabalho escravo e no cultivo de café. Com a crise de braços provocada pelo fim do tráfico negreiro com a África e o incremento do tráfico interprovincial, os proprietários passaram a enfrentar diversos problemas no que se refere à administração da escravaria ali existente. A maximização da exploração da mão de obra cativa, aliada ao crescimento da campanha abolicionista na região e à resistência escrava, deu origem a uma série de violentos conflitos entre senhores e escravos, os quais acabaram por acirrar as contradições entre as referidas classes sociais e interferir no processo de abolição da escravidão na região.
\end{abstract}

Palavras-chave: Colônia Leopoldina; escravidão; criminalidade; resistência escrava; luta de classes.

\begin{abstract}
This article aims to discuss the relationship between the slave crime and the decline of slavery in the Colony Leopoldina, located in Southern Bahia in the period 1880-1888. Initially designed to be a colony of foreign immigrants made up of small family units, the locality soon became an enterprise facing the agro-export agriculture based on slave labor and coffee cultivation. Along the labour crisis caused by the end of the slave trade with Africa and the increase in interprovincial traffic, the owners had faced several problems with the administration of existing slaves there. The maximum exploitation of captive
\end{abstract}

\footnotetext{
* Doutor em História pela UFPR e professor do Programa de Pós-Graduação Interdisciplinar - Mestrado em Ensino (PPIFOR), e do Colegiado de História da UNESPAR - campus de Paranavaí, E-mail: rictcaires@ gmail.com
} 
labor, allied with the growth of the abolitionist campaign in the region and slave resistance, gave rise to a series of violent conflicts between masters and slaves, which eventually intensified the contradictions between those classes and interfere in the process of abolition of slavery in the region.

Keywords: Colony Leopoldina; slavery; crime; slave resistance; class struggle.

\section{Uma colônia de estrangeiros na Bahia}

As primeiras políticas de imigração de colonos estrangeiros para o Brasil datam do fim do período colonial, mais especificamente após a transmigração da família real para o Brasil, em 1808. Naquele contexto, o governo português visava implantar núcleos familiares em locais estratégicos para o abastecimento da Corte, na cidade do Rio de Janeiro, ou ainda estabelecer grupos de povoamento em regiões de fronteira com vistas a ocupar e desenvolver localidades até então isoladas no território colonial. ${ }^{1}$ Uma destas experiências foi a Colônia Leopoldina, que ao que tudo indica, foi fundada pelo cônsul hamburguês Pedro Peycke, com o auxílio dos naturalistas Georg Wilheilm Freyreiss e Morhardt, em 1818. ${ }^{2}$ Localizada no extremo sul da Bahia, no município de Vila Viçosa, hoje Nova Viçosa, pertencente à comarca de Caravelas, a colônia foi inicialmente concebida para ser uma colônia de "povoamento", formada tipicamente por estrangeiros que ali viveriam em pequenos núcleos familiares. ${ }^{3}$

\footnotetext{
${ }^{1}$ NICOULIN, Martin. A gênese da Nova Friburgo. Emigração e colonização suíça no Brasil (1817-1827). Rio de Janeiro: Fundação Biblioteca Nacional, 1995.

${ }^{2}$ Sobre a fundação da colônia ver, dentre outros, OBERACKER JR, Carlos. H. A colônia Leopoldina-Frankental na Bahia meridional: uma colônia européia de plantadores no Brasil”. In: RIHGB: Rio de Janeiro, v. 148 (1987), pp 116-140; CORRÊA, Lucelinda Schramm. A torturante ausência de uma presença. A imigração alemã na Bahia do século XIX. Um estudo de caso. Tese de Doutoramento. São Paulo: PPGH/USP, 2003; OLIVEIRA, Waldir Freitas. A saga dos suíços no Brasil, 1557-1945. Joinville SC: Ed. Letradágua, 2007.

${ }^{3} \mathrm{O}$ termo colônia de povoamento é uma alusão ao conceito empregado por PRADO JÚNIOR, Caio. História econômica do Brasil. $6^{a}$ ed. São Paulo: Brasiliense, 1961, p. 22.
} 
Mapa 01 - Extremo sul da Bahia no final do século XIX

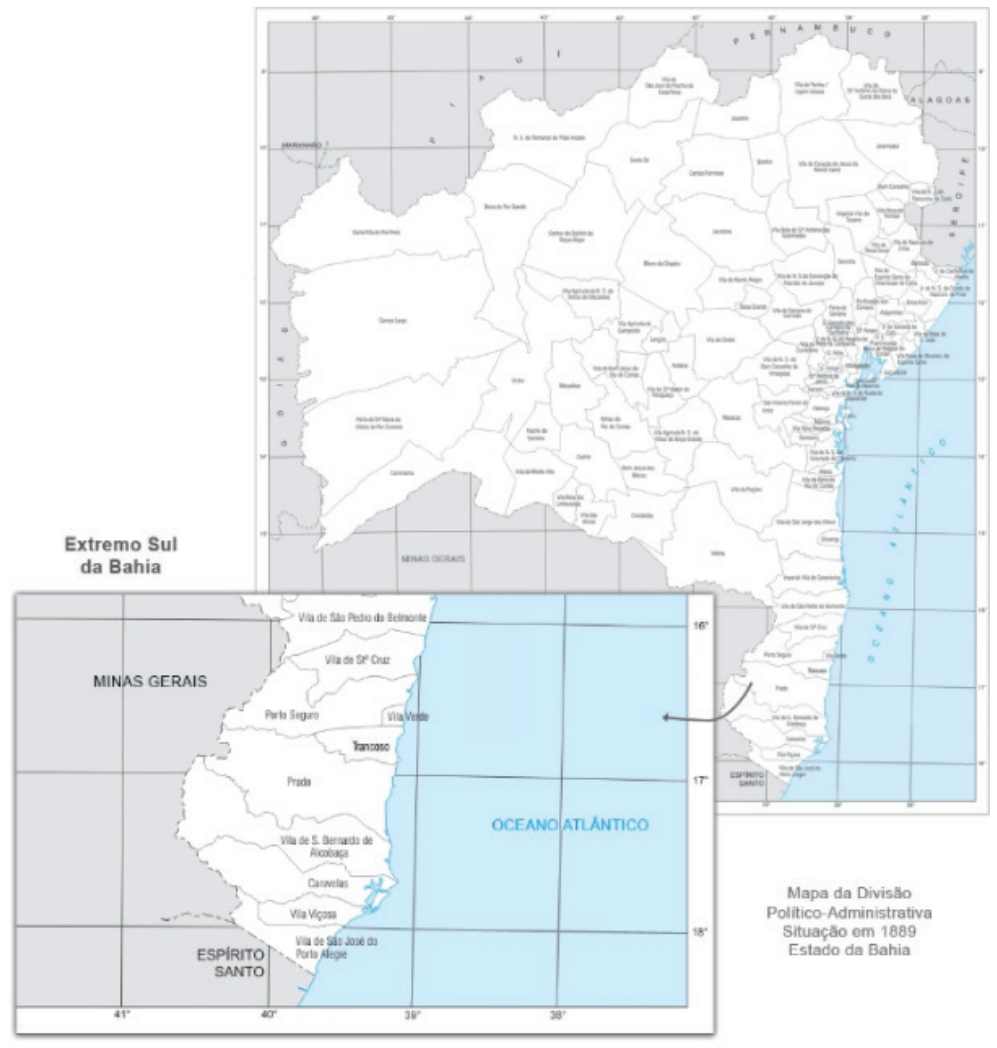

Fonte: Evolução territorial e administrativa do Estado da Bahia. Um breve Histórico. Salvador, Ba: SEI, 2003.

A fundação da colônia contou com o apoio oficial de D. João VI, sendo o nome desta uma homenagem prestada pelos fundadores à Maria Leopoldina de Áustria, primeira esposa do príncipe D. Pedro, a qual "muito contribuiu para que lhe fossem dadas essas terras". ${ }^{4}$ De início, as atividades produtivas eram realizadas exclusivamente por trabalhadores livres. Porém, diante da falta de novos imigrantes, não tardou para que a colônia tivesse sua a feição modificada, tendo para tanto contribuído a utilização em larga escala do trabalho escravo para o cultivo de um gênero de exportação que àquela altura

${ }^{4}$ Ver NEESER, Herman. A colônia Leopoldina. Salvador, Ba: CEB, 1951, p. 04. 
começava a despontar na pauta de exportações do Brasil: o café. ${ }^{5}$ Nesse sentido, muitos foram os estrangeiros que viram nas terras localizadas no extremo sul da Bahia a oportunidade de enriquecimento e prosperidade.

Fazenda Pombal, Colônia Leopoldina, Bahia, na primeira metade do século XIX. Bosset de Luze. Aquarela sobre papel, 25,5 x $57 \mathrm{~cm}$

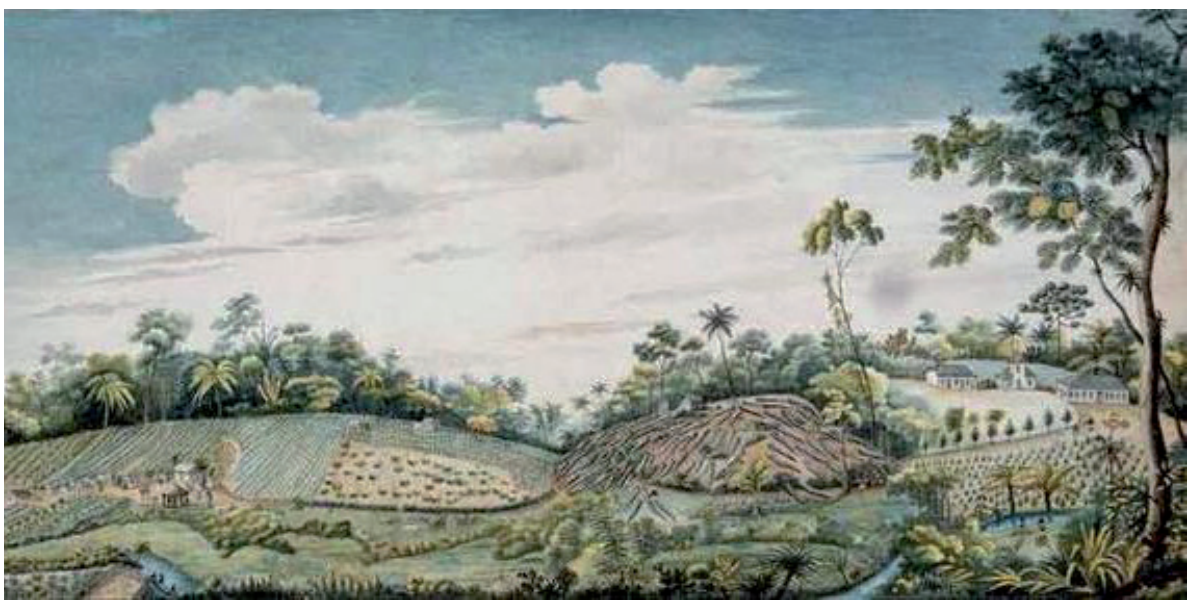

Fonte: Pinacoteca do Estado de São Paulo.

Dessa forma, já em meados do século XIX, e guardadas as devidas proporções, a Colônia Leopoldina podia ser considerada como o maior exemplo de propriedade sedimentada no regime de grande plantation fora do Recôncavo baiano. ${ }^{6} \mathrm{Na}$ viagem que empreendeu pelas comarcas do sul baiano em janeiro de 1852, o presidente da província Francisco Gonçalves Martins (1807-1872), ao passar no distrito de Viçosa, teve oportunidade de visitar

algumas famílias Estrangeiras, sendo a maior parte Suíços, que bastante tem contribuído para a riqueza e civilização do Município, influindo muito favoravelmente também sobre o porto de Caravelas por onde se exportam já suas 70 mil arrobas de café, além de outros gêneros de consumo. Esta povoação agrícola conhecida por denominação de - Colônia Leopoldina - conta pouco mais ou menos 54 pessoas Estrangeiras; 400 brasileiros, entrando neste último número 50 filhos daqueles; e cerca de 1.600 escravos. $^{7}$

\footnotetext{
${ }^{5}$ OBERACKER JR, op. cit., pp.469-475.

${ }^{6}$ BARICKMAN, Bert. J. Um Contraponto Baiano. Açúcar, fumo, mandioca e Escravidão no Recôncavo, 1780-1860. Rio de Janeiro: Civilização Brasileira, 2003, p.63.

${ }^{7}$ FALA que recitou o presidente da província da Bahia, o desembargador conselheiro Francisco Gonçalves Martins na abertura da Assembleia Legislativa da mesma província no dia $1^{\circ}$ de março de 1852. Bahia. Typ.
} 
Naquela ocasião, o futuro barão e visconde de São Lourenço teceu muitos elogios às plantações e estabelecimentos da colônia, onde "a ordem e a perfeição indicam a presença esclarecida da indústria europeia". ${ }^{8}$ Este exemplo, aliás, pareceu animá-lo a incentivar e apoiar a imigração, pois "a moral que se nota em toda a população e a dedicação ao trabalho aconselham toda a espécie de proteção para animar nova importação de braços europeus, e a vinda dos parentes e amigos dos já estabelecidos". ${ }^{9}$ Segundo o relato de um dos moradores da colônia, o médico e fazendeiro Carl August Töelsner, que em 1858 escreveu uma dissertação sobre a colônia com vistas à aquisição do título de doutor em Filosofia na Universidade de Göettingen, na Alemanha, àquela época, o lugar contava com " 40 fazendas, nas quais viviam 200 brancos, na maioria alemães e suíços, alguns franceses e brasileiros e, 2.000 pretos". ${ }^{10}$ A estimativa acerca da população escrava é confirmada pelas informações contidas no relatório da presidência da província, onde consta que "o lugar é hoje habitado por uma grande maioria de estrangeiros proprietários de fazendas de plantações de café, cuja cultura, especial do lugar, é particularmente confiada a dois mil cativos pouco mais ou menos". ${ }^{11}$ Como se pode perceber, a presença escrava na colônia era esmagadora, perfazendo 10/1 quando comparada aos brancos; proporção que se eleva ainda mais quando aplicada às maiores propriedades dali. ${ }^{12}$ Aliás, sobre os escravos, Töelsner também informou que estes, em sua maioria,

nasceram e se criaram quase todos na colônia e devem isto ao tratamento humanitário que lhes é despendido e, à vantagem de viverem em descentes e respeitáveis núcleos familiares. Todos são batizados, educados como cristãos e bem tratados. A maioria dos rapazes são admitidos ao estudo de um ofício, as meninas são instruídas em trabalhos caseiros. ${ }^{13}$ [Grifos meus].

A descrição feita por Töelsner pode indicar a forma de organização que os estrangeiros se valerem para controlar os escravos. Ou seja, o estímulo à

\footnotetext{
Const. de Vicente Ribeiro Moreira, 1852, p. 45.

${ }^{8}$ Ibidem.

${ }^{9}$ Ibidem.

${ }^{10}$ NEESER, op. cit., p. 04.

${ }^{11}$ FALA recitada na abertura da Assembleia Legislativa da Bahia pelo presidente da província, o conselheiro e senador do império Herculano Ferreira Penna, em 10 de abril de 1860. Bahia. Typ. de Antônio Olavo de França Guerra, 1860, p. 81.

${ }^{12}$ LUCCHESI, Dante; BAXTER, Alan; Ribeiro, Ilza (Orgs.). O português afro-brasileiro. Salvador: EDUFBA, 2009 , p. 87.

${ }^{13}$ NEESER, op. cit., p. 04. Esta descrição pode indicar a forma de organização que os estrangeiros se valerem para controlar os escravos.
} 
formação de núcleos familiares tinha por intuito garantir a 'paz das senzalas', como defenderam Manolo Florentino e José Roberto Góes. ${ }^{14}$ De fato, o perfil da escravaria existente ao longo da existência da colônia denota uma forte presença da família escrava nos plantéis. De igual maneira, a presença africana também foi constante, representando em torno de $50 \%$ da população cativa até meados do XIX, quando então o tráfico africano foi definitivamente suspenso. Ao que tudo indica, após o fim do infame comércio de escravos africanos, em 1850, os fazendeiros optaram por estimular ainda mais a reprodução endógena da escravaria, de modo a garantir braços para a continuidade das atividades produtivas, ou seja, da produção do café para exportação. ${ }^{15}$

\section{A produção do café Caravellas}

Como já foi dito, a principal atividade econômica da colônia era a produção de café, produto que, nas décadas de 1840 e 1850, já liderava as exportações brasileiras e cuja produção se concentrava majoritariamente nas lavouras do Sudeste. ${ }^{16}$ Ainda segundo nos informa o médico Carlos Augusto Töelsner, inúmeras máquinas movimentadas por força hidráulica eram usadas no preparo do "café Caravellas", como ficou conhecido aquele que para muitos "era considerado o melhor café do Brasil". ${ }^{17}$

Embora de início os colonos tenham enfrentado dificuldades no plantio e na colheita de diversos gêneros alimentícios, inclusive no cultivo do próprio café, a partir de meados da década de 1840 a prosperidade econômica da colônia era visível e, anos mais tarde, em 1852, dali já se exportava 70.000 arrobas deste produto. Na década seguinte, a produção saltou para "perto de 100.000 arrobas", as quais eram escoadas "em parte para a Bahia e em parte para o Rio de Janeiro em dois vapores contratados e postos à disposição especialmente para esse fim" ${ }^{18}$ Também faziam parte das atividades produtivas dos colonos

\footnotetext{
${ }^{14}$ FLORENTINO, Manolo e GÓES, José Roberto. A paz das senzalas: familias escravas e tráfico atlântico, Rio de Janeiro, c. 1970-c.1850. Rio de Janeiro: Civilização Brasileira, 1997.

${ }^{15}$ Sobre o perfil da escravaria da colônia ver BAXTER, Alan; LUCCHESI, Dante. Un paso más hacia la definición del pasado criollo del dialecto afro-brasileño de Helvécia (Bahia). In: ZIMMERMANN, Klaus (Ed.). Lenguas criollas de base lexical española y portuguesa. Madri: Iberoamericana, 1999. p.119-141; e FRAGA, CARMO, Alane Fraga do. Colonização e escravidão na Bahia: a Colônia Leopoldina (1850-1888). Dissertação (Mestrado em História). FFCH, UFBA, 2010, especialmente o capítulo 3.

${ }^{16}$ Sobre a importância do café na pauta de exportações do Brasil ver MARTINS, Ana Luiza. História do café. São Paulo: Contexto, 2008; STEIN, Stanley J. Vassouras: Um município brasileiro do café, 1850-1900. Rio de Janeiro: Nova Fronteira, 1990, especialmente o capítulo II.

${ }^{17}$ NEESER, op. cit., p. 05.

${ }^{18}$ COSTA, Emília Viotti da. "O escravo na grande lavoura”, in Holanda, Sérgio Buarque de (Org.) O Brasil monárquico. 5. ed, São Paulo, Difel, tomo II, vol. 3, 1985. p. 162; e NEESER, op. cit., p. 05.
} 
a extração de madeiras para exportação, sendo que para isto ali existiam 12 serrarias. Além disso, eram cultivados em escala não comercial "a jaqueira, a mangueira, a fruta pão, a banana e a laranja, o abacaxi, a mamona, a cana de açúcar, o algodão, fumo, o milho, a mandioca, da qual é feito a farinha e vários legumes". ${ }^{19}$

Com tais características e diante do expressivo desenvolvimento, desde muito cedo a Colônia Leopoldina deixou de ser considerada como uma colônia destinada apenas ao povoamento da região por meio de pequenos núcleos familiares, fossem eles migrantes ou imigrantes. Tal fato já era sobejamente conhecido pelas autoridades baianas pelo menos desde meados da década de 1850 , ocasião em que já se estudavam os primeiros contratos destinados a promover a colonização na província tendo em vista a certeza da futura falta de braços para a lavoura por conta do fim do tráfico africano. Em 1855, por exemplo, o presidente da província João Maurício Wanderley avaliava a economia local como "relativamente florescente", e informava que a colônia não podia "ser considerada uma colônia regular; por quanto na agricultura empregam-se quase exclusivamente braços escravos". ${ }^{20}$ Anos mais tarde, o juiz Municipal do termo de Caravelas informava à presidência da província que "julgava dever não dar as informações exigidas pelo Aviso do Ministério do Império de 6 de setembro de 1859 sobre outras Colônias, porque no estado, em que se acha, não pode ser ela como tal considerada". ${ }^{21} \mathrm{Em} \mathrm{1861}$, as autoridades da província voltaram a afirmar que "a Colônia - Leopoldina - no Sul, não existe mais, pois que está toda transformada em fazendas de café de ricos proprietários, quase todos estrangeiros: aí, nessas fazendas trabalham seguramente 2.000 escravos". ${ }^{22}$

Ao logo das décadas seguintes, a economia da colônia só prosperou. Para termos uma ideia da pujança financeira de seus fazendeiros, examinemos o inventário de um deles. Trata-se de João Martinus Flach, casado com dona Ada Flach Gerver e pai de quatro filhos: João, Carlos, Arthur e James Flach. Falecido no ano de 1863, João Flach deixou para os herdeiros as fazendas Helvécia I e II e um formidável plantel de trabalhadores, compostos de 149

\footnotetext{
${ }^{19}$ NEESER, op. cit., p.5.

${ }^{20}$ FALA recitada na abertura da Assembleia Legislativa da Bahia pelo presidente da província, o doutor João Maurício Wanderley, no dia $1^{\circ}$ de março de 1855. Bahia. Typ. de Antônio Olavo de França Guerra, 1855, p.40.

${ }^{21}$ FALA recitada na abertura da Assembleia Legislativa da Bahia pelo presidente da província, o conselheiro e senador do império Herculano Ferreira Penna, em 10 de abril de 1860. Bahia. Typ. de Antônio Olavo de França Guerra, 1860, p.80.

${ }^{22}$ FALA recitada na abertura da Assembleia da Bahia pelo presidente da província, Antônio Costa Pinto, no dia $1^{\circ}$ de março de 1861. Bahia. Typ. de Antônio Olavo de França Guerra, 1861, p. 35.
} 
escravos, sendo 77 homens e 72 mulheres, os quais habitavam uma "senzala quadrada coberta de telhas, parede de tijolos com 38 portas avaliadas em 3 contos de réis". ${ }^{23}$ Além disso, em suas terras estavam plantados "40 mil pés de café de 11 anos; 50 mil pés de 09 anos; 30 mil de 08 anos; 50 mil de 05 anos; 60 mil pés de 04 anos; 14 mil pés de 01 ano e 10 mil pés de 02 anos"; ou seja, ao todo, 224 mil pés de café. ${ }^{24}$ Flach ainda possuía uma chácara nos arrabaldes do Rio de Janeiro, denominada Engenho Novo, local que ficou bastante valorizado após o estabelecimento de uma estação ferroviária ligada à estrada de ferro D. Pedro II. ${ }^{25}$

Em 1877, ao queixar-se em correspondência ao presidente da província sobre o procedimento das autoridades da Comarca Municipal, que não oferecia os livros para execução da Lei do Registro Civil, o padre Geraldo Xavier de Sant'Anna - personagem que abordaremos mais adiante - sinalizava a prosperidade econômica da região, ao informar que

Esta Comarca, Exm $^{\circ}$ Sr., quer passar por muito pobre, quando possui grandes rendimentos anuais que, entre muitos outros, lhe concede a exportação de café e da farinha da Colônia Leopoldina e Pau Alto; e não obstante nunca tem dinheiro para cumprir suas obrigações e tratar dos melhoramentos do município. ${ }^{26}$

E esta riqueza só foi possível graças ao emprego do braço escravo bem como à valorização do preço do café nos mercados externos ao longo da segunda metade do século XIX. Contudo, a partir da década de 1880, esta realidade começou a mudar. A partir de então, a expansão da cultura do café para outras regiões da província - notadamente para o Recôncavo - e a queda no preço do produto em 1882, somada às dificuldades de reposição de mão de obra por conta dos efeitos do tráfico interprovincial, da resistência escrava e da campanha abolicionista, impuseram os proprietários sérios desafios. ${ }^{27}$ Assim, diante da lentidão da reprodução endógena da escravaria e das limitações na renovação dos plantéis, o aumento e a fiscalização do ritmo de trabalho tornou-se uma das saídas encontradas pelos proprietários locais para manter

\footnotetext{
${ }^{23}$ APEBA. Seção Judiciária. Série: Inventário. Partes: João Flach e Ada Flach Gerver. Local: Caravelas. Class: 04/1482/1951/07. Ano: 1863.

${ }^{24}$ Idem.

${ }^{25}$ Idem. Para a análise de mais inventários e testamentos de outros destacados proprietários da Colônia ver CARMO, op. cit., pp.48-54.

${ }^{26}$ APEBA. Seção Colonial e Provincial. Série: Vigários. Maço 5225 (1849-1879).

${ }^{27}$ GOVERNO DO ESTADO DA BAHIA. A inserção da Bahia na evolução nacional. $1^{\underline{a}}$ etapa:1850-1889 - Atividades produtivas. Salvador, Ba: SEPLANTEC, 1978.
} 
os elevados níveis de produtividade. Tratava-se de extrair ao máximo a mais valia absoluta dos trabalhadores escravizados..$^{28}$

Por isso, e tal qual acontecido em outras regiões brasileiras onde o ritmo de trabalho dos escravos e a política de concessão de alforrias foi drasticamente alterado em razão da crise de mão de obra escrava, os problemas entre escravos, feitores e senhores não tardaram a aparecer. ${ }^{29}$ Examinemos alguns destes violentos conflitos, tidos aqui como expressão mais radical da luta de classes entre senhores e escravos.

\section{A sublevação dos escravos da fazenda Monte Christo}

No dia 05 de dezembro de 1882 os escravos da fazenda Monte Christo se levantaram violentamente contra o feitor da propriedade, chegando ao ponto de quase assassiná-lo. De acordo com as informações prestadas pelo Juiz Municipal do termo de Viçosa, José Pinto Ferreira de Oliveira, ao presidente da província Pedro Luiz Pereira de Souza, os cativos "tinham dado dois tiros no feitor da mesma fazenda; e que esses escravos, em número de 200, estavam revoltados, receando-se graves acontecimentos com a sublevação de outros das demais fazendas". ${ }^{30}$

Segundo Arnold Wildberger, a sublevação dos escravos fazenda da Monte Christo tinha sido provocada pelo "horrível tratamento dado aos escravos pelos europeus, proprietários daquela colônia". ${ }^{31}$ Esta afirmação, aliás, é um forte indicativo de que os morigerados imigrantes europeus também podiam facilmente adotar as tradicionais práticas de controle senhorial utilizadas pelos demais proprietários, como o trabalho feitorizado, inclusive por escravos, como veremos mais adiante. Contudo, de acordo com Alane Fraga do Carmo, o levante parece ter tido outra motivação. É que a propriedade em questão, uma das maiores e mais antigas de toda a colônia, era fruto de uma

\footnotetext{
${ }^{28}$ Tal estratégia também foi amplamente aplicada nas lavouras paulistas. Ver MACHADO, Maria Helena P. T. Crime e escravidão. São Paulo: Brasiliense, 1987, p. 95. A autora aprofunda essa discussão no capítulo "senhores e escravos na construção do sonho da terra", na obra O Plano e o Pânico: Os Movimentos Sociais na Década da Abolição. Rio de Janeiro: Editora EFRJ, EDUSP, 1994, pp. 21-66. Sobre o conceito de mais valia ver MARX, Karl. O capital: crítica da economia política. Rio de Janeiro: Bertrand Brasil, 1994, 3 vols.

${ }^{29}$ MACHADO, op. cit., especialmente a segunda parte da obra.

${ }^{30}$ FALA com que o Exm ${ }^{\circ}$ Sr. Conselheiro Pedro Luiz Pereira de Souza abriu a $2^{a}$ sessão da $24^{a}$ legislatura da Assembleia Provincial da Bahia em 03 de abril de 1883. Bahia: Typographia do Diário da Bahia, 1883, p. 63-64. Na verdade, a fazenda possuía 165 escravos e não 200, como informado pelo Juiz Municipal número que, ainda assim, não deixa de impressionar. Também é notório o acesso que estes tinham ao porte de armas de fogo.

${ }^{31}$ Ver WILDBERGER, Arnold. Os presidentes da província da Bahia. Efectivos e interinos (1824-1889). Salvador, Ba: Typographia Beneditina, 1949, p. 716.
} 
sociedade entre o vice-cônsul da Suíça no Brasil, Frederico Luiz Jeanmonod, e o tenente-coronel Augusto Beguim. Com cerca de 900 braças (cerca de $1.980 \mathrm{~m}$ ) de frente e fundo, a fazenda Monte Christo estava localizada na margem norte do rio Peruípe e, no ano anterior ao levante, ou seja, em 1881, chegou a produzir 1.200 arrobas de café. Nela também se produzia farinha e se fabricavam telhas. A propriedade ainda contava com tenda de ferreiro, carpina e casa para hospital. ${ }^{32}$

Frederico Luiz Jeanmonod, era agente consular em Caravelas desde o ano de 1861 e além desta propriedade era dono da vizinha fazenda Califórnia, onde trabalhavam 129 escravos. Além disso, também era acionista em outras terras na região; sendo, portanto, um dos homens mais ricos e influentes de toda a colônia. ${ }^{33}$ Porém, era Augusto Beguim quem morava e dirigia pessoalmente a fazenda Monte Christo desde a sua aquisição, no final da década de 1850. Beguim parecia gozar de bastante prestígio político na localidade e também na região, pois no começo da década de 1880 exercia os cargos de juiz de paz do $2^{\circ}$ distrito e também o presidente da Câmara Municipal da Vila Viçosa.

Augusto Beguim esteve à frente da administração da propriedade até o seu falecimento, no começo de abril de 1881. Sua morte certamente foi recebida com muita apreensão por parte dos escravos, pois geralmente a morte dos senhores podia representar mudanças radicais em suas vidas; tanto no sentido positivo, ou seja, a conquista da liberdade, quanto negativo, como a piora nas condições do cativeiro ou a venda para outros senhores e até para outras paragens. Desde então, os cativos pareciam aguardar ansiosos o que o destino lhes reservava. Conforme bem observou Sidney Chalhoub

\begin{abstract}
Mais que um momento de esperança, porém, o falecimento do senhor era para os escravos o início de um período de incerteza, talvez semelhante em alguns aspectos à experiência de ser comprado ou vendido. Eles percebiam a ameaça de se verem separados de familiares e de companheiros de cativeiro, havendo ainda a ansiedade de adaptação ao jugo de um novo senhor, com todo um cortejo desconhecido de caprichos e vontade..$^{34}$
\end{abstract}

\footnotetext{
${ }^{32}$ Além de café, a fazenda também produzia farinha. Quando da abertura do inventário de Augusto Beguim, as terras e benfeitorias foram avaliados em 14:440\$000 (quatorze contos, quatrocentos e quarenta mil réis) e os escravos em 27:760\$000 (vinte e sete contos, setecentos e sessenta mil réis), ou seja, quase o dobro. Ver CARMO, op. cit., p.53.

${ }^{33}$ Ibidem.

${ }^{34}$ CHALHOUB, Sidney. Visões da Liberdade: Uma história das últimas décadas da escravidão na corte. São Paulo: Companhia das letras,1990, p.111.
} 
Esta espera durou cerca de um ano e meio e terminou no dia em que finalmente foi feita a partilha dos bens da aludida sociedade. Na divisão, coube a Frederico Jeanmonod 94 dos 163 cativos avaliados no inventário de seu falecido sócio. Dos 69 escravos restantes, 24 foram libertados em testamento e os demais, ao todo 45, foram comprados pelo próprio Jeanmonod no dia 05 de dezembro de 1882, data em que eclodiu o levante. ${ }^{35}$ Assim, podemos supor que o medo e a insegurança de viverem sob um novo senhorio ou mesmo a ameaça da venda para outras paragens teria contribuído decisivamente para a ocorrência da revolta na fazenda Monte Christo.

As providências para a repressão aos revoltosos foram tomadas na mesma rapidez com que o presidente da província recebeu o telegrama da estação de Peruípe. De imediato, o conselheiro Pedro Luiz Pereira de Souza ordenou que um oficial acompanhado de alguns praças se reunissem no destacamento de Caravelas e dali partissem para a Colônia Leopoldina. Da capital, também foram enviados mais um oficial e outros 23 praças. Na própria colônia, prestaram socorro o Juiz Municipal de Vila Viçosa, o já mencionado Frederico Jeanmonod e o também fazendeiro José Antônio Venerote. No total, mais de 30 homens formavam o destacamento que reprimiu a sublevação, a qual teve como saldo a prisão de "diversos escravos, que estavam armados e que depois foram soltos, sendo nove recolhidos à cadeia de Villa Viçosa, como suspeitos de terem concorrido para que se revoltassem contra o feitor da fazenda, e se recusassem ao trabalho". ${ }^{36}$

Infelizmente não consegui localizar o processo-crime resultante deste evento, pois acredito que estes autos certamente trariam valiosas informações prestadas pelos cativos - ainda que filtradas pela pena das autoridades policiais. Por isso, ficamos sem saber efetivamente o porquê da revolta, quantos cativos tomaram parte na mesma, quem eram seus líderes, etc. A venda, logo após o levante, dos escravos Renorato, Vencesláu, Marcolino e Benvinda, no entanto, aponta para a participação qualificada destes indivíduos no episódio. Teriam sido eles os cabeças da sublevação?

Dúvidas a parte, e de acordo com o balanço feito pelo presidente da província, para sorte de todos, e apesar dos ferimentos provocados no feitor, "não houve incidente algum a lamentar" - a não ser o medo de que a "onda

\footnotetext{
${ }^{35}$ CARMO, op. cit., p. 72.

${ }^{36}$ Ibidem, p.64.
} 
negra" se espalhasse pelas demais propriedades da colônia e da região. ${ }^{37}$ Medo este que, como veremos a seguir, tinha todo fundamento.

\section{$\mathrm{O}$ assassinato do fazendeiro José Antônio Venerote}

Decorrido pouco mais de um ano, mais precisamente na noite de 25 de abril de 1884, um novo fato abalaria a tranquilidade nas fazendas cafeeiras da colônia. Nesse dia, os escravos Anselmo, Rodolfo, Valério, José, Simeão, Leonardo e Cristiano assassinaram o fazendeiro José Antônio Venerote, antigo e importante proprietário de terras na colônia Leopoldina e que, como vimos, foi um dos que auxiliaram as autoridades policiais na contenção da revolta dos escravos da fazenda Monte Christo. ${ }^{38}$ Devido à brutalidade e semelhança com outros casos de assassinatos de senhores e feitores ocorridos na década de 1880 , o caso ganhou imediata repercussão na imprensa, como noticiou o Diário de Notícias, da Bahia, no dia 02 de maio de 1884:

Os autores de tão bárbaro crime foram os escravos da fazenda Mutum, ultimamente comprados pelo Sr. Venerote. Os assassinos, no próprio dia em que mudaram de senhor, declararam que não serviriam aquele que pretendia possuí-los.

O cadáver, conforme já dissemos, foi encontrado na manhã do dia seguinte, por volta das 8 horas. Estava em um estreito caminho que ia ter à fazenda Mutum; todo o frontal e parte do crânio estavam despedaçados, o couro cabeludo solto na maior parte, nas costas grandes contusões e manchas negras.

Os assassinos serviram-se de armas contundentes.

Junto ao cadáver, além de outros objetos, acharam-se dois chapéus ordinários, cujos donos ficaram sendo conhecidos.

À roda do cadáver puseram os assassinos moitas de galhos e folhas, a fim de ocultarem; entre esses galhos foram achados quatro cassetetes rachados e manchados de sangue.

Sabe-se que os assassinos se internaram no mato. ${ }^{39}$

Como se pode perceber da leitura dos dados contidos na matéria, os cativos planejaram uma emboscada para matar o italiano Venerote, pois o crime ocorreu à noite, num estreito caminho que dava acesso à fazenda,

${ }^{37}$ AZEVEDO, Célia Maria Marinho de. Onda negra, medo branco: o negro no imaginário das elites. Século XIX. Rio de Janeiro: Paz e Terra, 1987.

${ }^{38}$ Antônio Venerote também era dono da a fazenda Piqui de Cima, cuja soma de bens - propriedade, bens de raiz e escravos - foi avaliada em 143:759\$000 réis. Ver CARMO, op. cit., p. 129.

${ }^{39}$ DIÁRIO DE NOTÍCIAS, Bahia, 02 de maio de 1884. Essa mesma notícia foi replicada pelo JORNAL DO RECIFE de 09 de maio de 1884, n 107, página 01 e também pelo JORNAL DO COMÉRCIO, do Rio de Janeiro, de 08 de maio de $1884, n^{\circ} 128$, página 03 . Outras gazetas brasileiras também noticiaram o assassinato, ainda que sem fornecer mais detalhes do crime. Todos os periódicos citados neste artigo foram consultados on line no site da Biblioteca Nacional, projeto Hemeroteca Digital, no endereço: http://memoria.bn.br/hdb/periodico.aspx. 
possivelmente quando este retornava para a propriedade que recém-adquirira. $O$ fato de estarem munidos de cassetetes também indica a premeditação do delito. Cabe destacar que a fazenda Mutum havia sido comprada há menos de um mês pela vítima junto aos familiares e herdeiros de Antônio Pires de Carvalho, membro de outra destacada família da colônia.

Levando-se em conta estes dados, podemos inferir que, assim como no caso anterior, a motivação principal para o assassinato fora a repentina mudança de senhor, cujos predicados os cativos pareciam conhecer. Afirmo isto porque, como indicou Alane Fraga do Carmo, José Antônio Venerote estava ligado ao comércio compra e venda de escravos na região. ${ }^{40}$ Suponho que os cativos temiam serem vendidos para outras regiões da província, perdendo assim seus laços familiares e afetivos - como acontecera com milhares de escravos baianos engajados no tráfico interprovincial -, e por isso planejaram matar seu novo senhor. ${ }^{41}$

Também há fortes indícios de que os cativos tenham sido de alguma forma influenciados pela propaganda abolicionista. ${ }^{42}$ Digo isso porque ao analisar uma ação cível de liberdade movida em agosto de 1884, portanto quatro meses depois do crime, pelos escravos Targino, João e Vicentina contra Francisco Correia do Nascimento, me deparei com uma acusação feita pelo defensor do pretenso proprietário dos escravos sobre a existência de pessoas aconselhando os cativos a se insurgirem contra seus senhores e que isto andava a surtir efeito, haja vista que

toda a Comarca ouviu gritos de horror por fatos praticados contra seus senhores, como o caso de dar-se com o fazendeiro na Colônia Leopoldina José Antônio, morto vítima de sete escravos aconselhados, como confessam, morto barbaramente a cacete.$^{43}$ [Grifos meus].

Infelizmente também não consegui localizar os autos criminais referentes ao assassinato de José Antônio Venerote para cotejar a versão dos fatos na ótica dos escravos. Sabemos, contudo, que no dia 11 de abril de 1886 os

\footnotetext{
${ }^{40}$ CARMO, op. cit., p. 79.

${ }^{41}$ SILVA, Ricardo Tadeu Caires. Caminhos e descaminhos da abolição. Escravos, senhores e direitos nas últimas décadas da escravidão. Bahia, 1850-1888 (Tese de Doutorado, UFPR), 2007, especialmente o capítulo 3.

${ }^{42}$ Sobre o movimento abolicionista na Bahia ver BRITO, Jaílton Lima. A abolição na Bahia (1870/1888), Salvador: Centro de Estudos Baianos da UFBA, 2003; GRADEN, Dale. From slavery to freedom in Brazil. Bahia, 1835-1900. Albuquerque: University of New Mexico Press, 2006, especialmente o capítulo 7.

${ }^{43}$ Ver APEBA. Seção Judiciária. Ação de Liberdade. Class: 52/1839/09. Autores: Targino, João, Vicentina X Francisco Correia do Nascimento. Ano: 1884. A alegação dos escravos na moção da ação era de que eram netos do sitiante e por isto este havia lhes passado carta de liberdade. O juiz de Direito da Comarca julgou a ação improcedente.
} 
sete cativos foram condenados em primeira instância à pena galés perpétuas pelo júri de Vila Viçosa. ${ }^{44}$

Mas, naquele contexto de tensão social, a violência não vitimou apenas os senhores e seus prepostos: os cativos também sentiram na pele e na alma as dores da opressão a que o regime escravista os expunha cotidianamente.

\section{Tragédia na fazenda Sapucaeira}

Numa manhã do dia 03 de agosto de 1883, como era de costume, os cativos da fazenda Sapucaeira foram mobilizados a se dirigirem ao eito para dar início à limpa dos cafezais. Ao realizar a conferência dos escravos, Anastácio, feitor da fazenda, se deu conta de que faltava alguém. $O$ atraso da escrava Firmina, contudo, tinha um motivo nobre. Ela estava alimentando os filhos ingênuos, Pamphílio e Gregório, e por isso perdera a hora de se juntar ao grupo. Este ato, contudo, não foi perdoado pelo feitor, o qual, ao vê-la chegar ao eito, imediatamente tratou de castigá-la na frente dos demais, dando-lhe algumas chicotadas.

O castigo imprimido a Firmina desagradou profundamente ao crioulo Laurindo, de 25 anos, seu amásio, que ato contínuo tentou agredir o feitor com a enxada que trazia - no que foi contido e demovido desta ideia pelos parceiros de cativeiro. Desnorteado e enfurecido, Laurindo pôs-se então em direção à senzala em que vivia com a família e ali chegando desferiu duros golpes de enxada contra a cabeça de seus filhinhos, assassinando-os brutalmente. ${ }^{45}$

As razões para tamanho ato de desespero foram dadas pelo próprio Laurindo, no interrogatório feito pelo $1^{\circ}$ suplente do cargo de subdelegado, Henrique Hortsche, quando de sua prisão. Ao ser confrontado com os dois filhos mortos, o escravo disse

que reconhecia os dois cadáveres de Pamphilio e Gregório serem os de seus filhos, e que lhes tinha dado a morte com a própria enxada que estava a trabalhar, dado em cada um dois golpes com o corte da mesma. Disse mais, que praticara isto supondo que assim terminasse os grandes sofrimentos

\footnotetext{
${ }^{44}$ A condenação foi repercutida pelo JORNAL DO RECIFE, terça-feira, 18 de maio de 1886, $n^{\circ}$ 112, página 01.

${ }^{45}$ Dos autos de corpo de delito consta que "Pamphílio recebeu um ferimento no alto do crânio com dez centímetros de comprimento e cinco de profundidade; e no cadáver de Gregório igual brecha ao lado esquerdo da cabeça". APEBA. Seção Judiciária. Série: Homicídio. Class: 20/693/10. Réu: Laurindo X Vítimas: Pamphílio e Gregório. Ano: 1883. Sobre outros casos de filicídio no Brasil escravista ver FLORENTINO, Manolo; GOES, Roberto J. A paz nas senzalas. Familias escravas e tráfico atlântico. Rio de Janeiro, 1790-1850. Rio de Janeiro: Civilização Brasileira, 1997, pp.15-22; MATTOS, Hebe Maria. Das cores do silêncio. Rio de Janeiro: Nova Fronteira, 1999, pp. 112-115; ARAÚJO, Maria Bethânia de. "Uma foice e muitas lembranças: um caso de filicídio no Paraná escravista do século XIX." In: Revista Vernáculo [Online], 1.3 (2000).
} 
de Firmina, mãe dos mesmos, e não viessem eles seus filhos a sofrer mais tarde. E nada mais lhe sendo perguntado...6 [Grifos meus].

Esta versão dos fatos foi reconhecida e confirmada pelo feitor Anastácio, pivô da tragédia, crioulo, de 35 anos, também escravo. Perguntado se sabia o que havia ocasionado o fato criminoso, ele não hesitou em dizer que

sendo feitor, executava as ordens de seu senhor, e se tendo demorado a escrava Firmina, ele lhe dera umas chicotadas para exemplo dos outros, o que fora repelido agressivamente pelo escravo Laurindo, amásio de Firmina, e tendo os outros seus parceiros proibido que tal sucedesse, Laurindo encolerizado correu para o rancho onde estavam seus dois filhos Pamphilio e Gregório, e lá com enxadadas lhe dera morte. E nada mais disse... ${ }^{47}$ [grifos meus].

O fato de Laurindo ter optado por dar cabo à vida dos próprios filhos indica o quanto o cativeiro sob o qual viviam era duro e penoso. Nesse sentido, o depoimento do feitor Anastácio é emblemático na caracterização do modo de como devia funcionar o ritmo de trabalho escravo nas grandes e médias propriedades nas duas décadas que antecederam o fim da escravidão no Brasil. Sem disponibilidade de aquisição de mão de obra farta e acessível como outrora, os senhores procuravam maximizar o quanto podiam a produtividade de seus plantéis e para isso aumentavam o ritmo de trabalho em suas propriedades - ainda que para tanto tivessem de transferir para os feitores a responsabilidade e o risco de tal empreitada. Assim, cada vez mais a disciplina tornava-se a palavra de ordem e a sua falta implicava em algum tipo de punição ou castigo para aqueles que por algum motivo ousassem desrespeitar as regras estabelecidas, como o fez involuntariamente a escravizada Firmina.

Analisando o papel desempenhado pelos administradores das plantations no sul escravista dos Estados Unidos, Eugene D. Genovese percebeu muito bem o modo como a função exercida por estes indivíduos - e aqui me permito comparar a função dos feitores a estes - era extremamente arriscada. Se de um lado se mostrassem por demais complacentes para com os escravos, corriam o risco de perderem sua autoridade frente a estes e ao senhor, pondo em xeque a continuidade do exercício de sua função e tudo o que ela podia simbolizar - inclusive a possibilidade da aquisição da liberdade, no caso dos feitores escravos ${ }^{48}$ De outro lado, caso se mostrassem por demais autoritários

\footnotetext{
${ }^{46}$ APEBA. Seção Judiciária. Série: Homicídio. Class: 20/693/10. Réu: Laurindo X Vítimas: Pamphílio e Gregório. Ano: 1883.

${ }^{47}$ Idem.

${ }^{48}$ GENOVESE, Eugene D. A terra prometida: o mundo que os escravos criaram. Rio de Janeiro: Paz e Terra, 1988, p. 43.
} 
e cruéis para com os cativos, corriam o risco de sofrerem com as queixas dos escravos, ou, o que era pior, sentirem na própria pele a fúria destes, como vimos momentos atrás no caso do feitor da fazenda Monte Christo, quer por pouco não foi morto pelos escravos da propriedade.

Ao estudar as tensões e os conflitos nas lavouras paulistas nas décadas de 1870 e 1880, Maria Helena Machado constatou que o feitor era "a figura catalisadora das tensões provenientes da disciplina do trabalho, pressionado fortemente pelo senhor para fazer frente à resistência do escravo" e por isso, se "transforma-se em alvo privilegiado de ataques". ${ }^{49}$ No caso dos feitores escravos, almejava-se que a solidariedade aos interesses senhoriais se sobrepusesse à possível identidade com seus parceiros de cativeiro..$^{50}$ Também era recorrente o fato de os feitores serem os primeiros a serem punidos quando as contendas com os cativos acabavam mal. Como lembra Genovese, "com frequência o senhor sumia de vista como o homem responsável pela situação em que se encontravam. Em defesa dos escravos, a periódica intervenção do senhor contra os excessos ressaltava sua autoimagem assim como, nas senzalas, sua imagem de protetor". ${ }^{51}$ Foi o que ocorreu no presente caso; pois diante da repercussão negativa do crime de filicídio, o escravo Anastácio imediatamente perdeu o posto de feitor.

Além de Anastácio, vários escravos da propriedade confirmaram de modo semelhante como ocorreu a tragédia, de forma que a autoria do crime não foi questionada. Aliás, todos também atestaram o bom comportamento do escravizado Laurindo, o qual era "cria da casa" e sempre foi bom "para os brancos e para seus parceiros", como se lê nos depoimentos dos escravos Gonçalo e Serafim. Por sinal, a alusão ao fato de Laurindo ser "cria da casa" indica que naquele contexto havia a presença de escravos vindos de outras regiões da província e talvez mesmo de fora desta, pois localizei cativos oriundos de Sergipe nos plantéis de outra fazenda da colônia. Retirados do seu habitat costumeiro e sobretudo, privados dos seus laços afetivo, de sociabilidade e solidariedade, estes "forasteiros" muitas vezes não se integravam facilmente à comunidade escrava local, acabando por vezes a se envolver em conflitos. ${ }^{52}$

\footnotetext{
${ }^{49}$ Ver MACHADO, op. cit., p. 67. Uma análise dos conflitos entre escravos e feitores nos engenhos do Recôncavo baiano é feita por FRAGA FILHO, Walter. Encruzilhadas da liberdade: histórias de escravos e libertos na Bahia (1870-1890). Campinas: SP: Editora da Unicamp, 2006, pp.46-49.

${ }^{50}$ MATTOS, Hebe Maria. Das cores do silêncio: os significados da liberdade no Sudeste escravista, Brasil século XIX. Rio de Janeiro: Nova Fronteira, 1998, p. 132.

${ }^{51}$ GENOVESE, op. cit., p. 43.

${ }^{52}$ Ver, nesse sentido, CASTRO, Hebe M. Mattos de. Laços de família e direitos no final da escravidão. In: ALENCASTRO, Luiz Felipe de (Org.). História da Vida Privada no Brasil: Império. São Paulo: Companhia das
} 
Diante da certeza da autoria do crime, o promotor Francisco Antônio de Carvalhal pronunciou Laurindo no grau máximo do artigo 192 do código penal, ou seja, pediu a aplicação da pena de morte. ${ }^{53}$ O julgamento do cativo, contudo, tardou a acontecer, pois decorreram dois anos até que a formação de culpa fosse concluída. A sentença, proferida em 15 de novembro de 1885, condenou-o a pena de galés perpétuas. Inconformado com este resultado e usando das prerrogativas legais, o advogado de Laurindo protestou para que houvesse um novo julgamento, o veio a ocorrer em 09 de abril de 1886. Diante da confirmação da sentença anterior, a defesa interpôs nova apelação para o Tribunal da Relação da Bahia, o qual, por sua vez, anulou todo o julgamento em vista das irregularidades processuais e ordenou que um novo júri fosse feito.

O terceiro julgamento de Laurindo aconteceu em 30 de maio de 1887, e desta vez ele foi condenado à pena de 06 anos de prisão com trabalho. Mais uma vez, a defesa do escravo apelou. $\mathrm{O}$ argumento utilizado agora era a irregularidade na realização do júri no termo de Caravelas e não em Vila Viçosa, como se dera nos dois casos anteriores. Protestando contra a atitude do promotor público da comarca de Caravelas, que desprezou o fato de ali existirem jurados suficientes para a nova sessão, o padre Geraldo Xavier de Sant'Anna, novo curador do escravo, solicitou ao Tribunal da Relação que um novo júri fosse marcado para que seu curatelado fosse absolvido em face de ter praticado o crime em estado de "loucura". Com esta alegação, o padre Geraldo Xavier de Sant'Anna possivelmente tentava atenuar ainda mais a pena de Laurindo em caso de nova condenação. ${ }^{54}$

O promotor Francisco Antônio de Carvalhal até que tentou rebater as alegações do padre, afirmando ainda que o curador do escravo "ocupou-se unicamente, em alta voz, da abolição da escravidão". Recebida a apelação, mais uma vez o Tribunal decidiu pela realização de um novo júri no termo de Vila Viçosa, como queria o defensor do escravo. A nova sessão de julgamento foi marcada para o dia 02 de julho de 1888, mas só veio a ocorrer no final daquele ano, conforme noticiou o Diário da Bahia:

\footnotetext{
Letras, 1997. p. 359-360.

${ }^{53}$ Ver TINÔCO, Antônio Luiz Ferreira. Código Criminal do Império do Brazil Annotado. Rio de Janeiro. Imprensa Industrial, 1886, p. 370.

${ }^{54}$ Sobre as condições atenuantes ver ALVES JÚNIOR, Thomas. Anotações Theoricas e Praticas ao Código Criminal. Rio de Janeiro. B. L. Garnier Editor, 1886. Tomo I, segunda parte, capítulo III - Das circunstancias aggravantes e attenuantes do crime, pp. 413-574.
} 
No dia 6 do corrente teve lugar no júri o julgamento do réu Laurindo Bornand, que fora absolvido unanimemente, sendo seu defensor o nosso distinto amigo vigário Geraldo, que por caridade sempre se presta aos pobres e infelizes..$^{55}$

Esta nova decisão deu a Laurindo a possibilidade de tentar reconstruir sua vida em liberdade, embora seja pouco provável que o mesmo tenha deixado de se penalizar pelo resto dos seus dias pelo "ato de desespero" ou de "loucura" que cometeu contra seus filhos.

Ao que tudo indica, foi depois da tragédia ocorrida na fazenda Sapucaeira que o padre Geraldo Xavier de Sant'Anna se aproximou do suíço Luiz Bornand, incentivando-o a converter-se ao abolicionismo. ${ }^{56}$ De fato, no dia 21 de abril de 1886, data do aniversário de sua esposa, e decorridos quase duas semanas do segundo julgamento que condenou o escravo Laurindo às galés perpétuas, o fazendeiro resolveu libertar todos os seus 95 escravos - à exceção de Laurindo, a quem preservou no cativeiro sob a alegação de não desampará-lo na justiça. ${ }^{57}$

Apesar destes gestos humanitários, não sei até que ponto o procedimento do fazendeiro refletia suas convicções pessoais acerca da abolição, as quais podiam ter mudado ou mesmo se reforçado depois do filicídio, ou se estava associada à tentativa de assegurar a lealdade dos ex-escravos em sua propriedade, evitando assim maiores prejuízos por conta da falta de mão de obra em futuro próximo..$^{58} \mathrm{O}$ próprio Bornand expressou seus sentimentos numa carta dirigida ao conselheiro Antônio Carneiro da Rocha, do partido liberal baiano, por ocasião das libertações que promoveu:

Como participei em 21 do passado, inaugurou-se na minha casa a era da liberdade; houve festa, muito entusiasmo por parte dos escravos; poucos sabiam de minhas intenções.

Desde então o trabalho vai de forma que não tenho de me arrepender de minha resolução.

\footnotetext{
${ }^{55}$ DIÁRIO DA BAHIA, n 03 , sábado, 05 de janeiro de 1889, página 01.

${ }^{56}$ Além de fazendeiro, Luiz Bornand exercia o posto de vice-cônsul da Suíça. Assim como outros proprietários estrangeiros da colônia, ele frequentemente viajava à Europa a negócios, ocasião em que repassava a administração da propriedade a conterrâneos como o lavrador Samuel Cruchand, de 68 anos de idade. Sobre a figura dos administradores na colônia ver CARMO, op. cit. p.46.

${ }^{57}$ A notícia da libertação dos cativos repercutiu na imprensa de toda a província baiana e até mesmo fora dela. Ver, por exemplo, O PAIZ, Rio de Janeiro, de 19 de junho de 1886, página 01; A REGENERAÇÃO, Desterro -RS, terça-feira, 13 de julho de 1886, página 02.

${ }^{58}$ Segundo repercutiu a GAZETA DA TARDE, do Rio de Janeiro, $n^{\circ}$ 106, de 11 de maio de 1886, páginas 02, as 95 libertações feitas pelo fazendeiro foram condicionadas.
} 
Acho-me aliviado na minha consciência, sinto-me outro homem, e nisso está a minha melhor recompensa. ${ }^{59}$

Segundo as próprias palavras do fazendeiro, seu gesto foi recebido com muito entusiasmo pelos escravizados. Tal ato, ao que tudo indica, também acabou afetando positivamente a rotina de trabalho na propriedade, pois ao que parece os libertos passaram a trabalhar com maior motivação. Aliás, uma das intenções dos senhores na concessão de cartas de alforrias nos anos finais da escravidão era a preservação da força de trabalho e, sobretudo, a manutenção dos laços de submissão e dependência dos ex-escravos; os quais, nutridos dos sentimentos de gratidão e lealdade, continuariam a gravitar na órbita senhorial..$^{60}$

Seja como for, o recebimento da notícia de que o fazendeiro suíço havia libertado sua numerosa escravaria encheu de entusiasmo o padre Geraldo de Sant'Anna. Naquela terça-feira, dia 27 de abril, data em que se celebrava a festa de São Benedito, o vigário fez de tal ato o motivo de suas pregações aos fiéis que lotavam a matriz de Nossa Senhora da Conceição da Vila Viçosa. Na oportunidade, disse o religioso, que estando

sobremodo satisfeito pelo ato generoso, humanitário e cristão, que acabara de praticar aquele meu amigo, tomando por assunto a solenidade do dia, fiz um discurso, onde per accidens tratei da questão servil e apresentando como um dos modelos na atualidade o dito fazendeiro Bornand, a quem cobri de merecidos aplausos, tanto maiores, quanto o dito fazendeiro não professa a religião católica; ao passo que disse os sexagenários em número de 180, conforme consta da relação apresentada pelo Agente Fiscal d'este termo, ainda não receberam suas cartas de alforria do juízo de órfãos, procedimento contrário a recente Lei de 28 de setembro [1885]. ${ }^{61}$

Como se vê, o padre aproveitava o momento de reunião espiritual para ocupar-se dos assuntos temporais, aqui no caso para militar em favor da campanha abolicionista. Este procedimento, aliás, era tudo o que reivindicava um outro destacado abolicionista baiano. Em A escravidão, o clero e o abolicionismo, publicada em 1887, o médico Luís Anselmo da Fonseca dedicou mais de dois terços de sua volumosa obra para denunciar a imobilidade do clero baiano e

\footnotetext{
${ }^{59}$ Esta notícia foi veiculada originalmente pelo Diário da Bahia de 08 de junho de 1886 e repercutida por outros periódicos do império, como O PAIZ, de 19 de junho de 1886, n 168, página 01 e A REGENERAÇÃO, de 13 de julho de $1886, n^{\circ} 151$, página 02. Cabe notar que o conselheiro Antônio Carneiro da Rocha, advogado de formação, foi contratado por Luiz Bornand para defender Laurindo no Tribunal da Relação da Bahia.

${ }^{60} \mathrm{~A}$ este respeito ver GEBARA, Ademir. 0 mercado de trabalho livre no Brasil. São Paulo: Brasiliense, 1986; CHALHOUB, op. cit.

${ }^{61}$ APEBA. Seção Colonial e Provincial. Série: Vigários. Maço 5231.
} 
brasileiro diante da escravidão, haja vista que, dado o seu potencial de mobilização perante a comunidade, em pouco tempo a causa abolicionista alcançaria seus objetivos. Na Bahia, por exemplo, havia 190 freguesias, ou seja, no mínimo 190 vigários que, como o padre Geraldo Xavier de Sant'Anna, podiam formar um verdadeiro exército propagandista. ${ }^{62}$ Mas quem era esse religioso?

\section{Um abolicionista "disposto a tudo": o padre Geraldo Xavier de Sant'Anna}

São poucas ou quase inexistentes as fontes a nos informar sobre a vida privada do padre Geraldo Xavier de Sant'Anna, de modo que nada sabemos sobre sua família, onde e quando foi ordenado, etc. Contudo, a repercussão de sua atuação política o coloca com o principal agente do abolicionismo na região das vilas de Viçosa e Caravelas. Ligado ao partido liberal, do qual era um dos líderes locais, este religioso não media esforços para defender a abolição da escravidão e por isso se envolveu em diversas polêmicas com escravocratas e autoridades locais. ${ }^{63}$

De fato, o padre Geraldo Xavier mostrava-se atento ao que acontecia em sua paróquia e denunciava em público a cumplicidades das autoridades judiciárias para com os interesses escravocratas. Um bom exemplo é a denúncia que fez no sermão acima mencionado contra o juiz José Pedreira Machado pelo fato do mesmo não ter providenciado a libertação dos sexagenários. Aliás, a animosidade existente entre o referido juiz e seus partidários e o vigário por pouco não terminou em tragédia, como relatou o padre em carta denúncia que apresentou ao presidente da província Theodoro Machado Freire Pereira da Silva. ${ }^{64}$

A agressão teria ocorrido no dia seguinte a este primeiro pronunciamento aos fiéis, ou seja, no dia 28 de abril de 1886. Desta feita, os festejos sacros homenageavam Santa Catarina e, como no dia anterior, o vigário não perdeu o ensejo e voltou a tratar do "elemento servil e dos profícuos resultados do trabalho livre". Desta vez, contudo, o vigário foi interrompido por “apartes inconvenientes" do juiz José Pedreira Machado, auxiliado pelo subdelegado João Pereira da Costa, pelo $3^{\circ}$ suplente do cargo de juiz Municipal, José Nogueira Maia, e também por João Bernardo Vieira Júnior, este último

\footnotetext{
${ }^{62}$ Ver Fonseca, op.cit., p.393.

${ }^{63}$ Nas pesquisas que realizei consegui apenas a informação que o mesmo chegou a ocupar cadeira de deputado na Assembleia Provincial, entre 1884-1885, e que veio a falecer, muito doente, em janeiro de 1898. Ver, CIDADE DO SALVADOR, Bahia, sexta-feira, 28 de janeiro de 1898, n³27, página 02.

${ }^{64}$ APEBA. Seção Colonial e Provincial. Série: Vigários. Maço 5231.
} 
empregado da linha telegráfica. Segundo o vigário, tal intervenção deixou o "povo" que assistia à missa indignado e as discussões rumaram para fora da igreja após o fim do culto e só foram pacificadas pela intervenção de "cidadãos conceituados". Porém, a confusão não terminou por aí. À tarde, quando se dava a procissão, um dos correligionários do juiz soltou um cavalo justamente quando o cortejo passava pelo centro da vila, tendo o animal quase derrubado a imagem do Senhor Crucificado da mão do padre, enquanto que o juiz Pedreira "da janela de seu sobrado aplaudia-o com grande prazer". ${ }^{65}$

Diante destes fatos e das ameaças dos "capangas" do juiz, o padre Geraldo Xavier de Sant'Anna solicitou ao presidente da província que tomasse providências que garantissem a sua vida bem como a liberdade para que pudesse exercer livremente o seu ministério, "porquanto me vejo privado de sair à rua especialmente à noite para qualquer ato paroquial, a fim de não sofrer desacatos dos capangas do referido juiz". ${ }^{66}$

A carta enviada pelo padre Geraldo Xavier de Sant'Anna em 05 de maio de 1886 chegou às mãos do presidente da província ao mesmo tempo em que a correspondência escrita pelo juiz José Machado Pedreira. Confirmando o conflito, este último relatou ao presidente Theodoro Machado Freire Pereira da Silva que o padre Geraldo Xavier de Sant'Anna

há algum tempo já entendeu de aproveitar-se da igreja para depois das missas e festas e por ocasião da leitura do edital para a nova matrícula dos escravos pregar a estes doutrinas revolucionárias contra os senhores e contra mim como juiz de órfãos, dizendo e procurando convencer que não há mais escravos e que meu dever era declarar todos libertos, o que não tenho feito por ser contrário à liberdade. ${ }^{67}$ [grifos meus]

Condenando veementemente a atitude do vigário, a qual julgava ilegal e até criminosa, pois soubera que nas pregações "era até aconselhado como permitido e lícito o assassinato de senhores", o juiz Municipal e órfãos dos termos de Viçosa e Porto Alegre tratou de ver de perto "o abuso que se cometia ao pé do altar", indo assistir à missa "para ter ciência própria do fato contra o qual se me reclama providências". ${ }^{68} \mathrm{E}$, para sua surpresa, tudo era verdade, pois após terminado o culto

\footnotetext{
${ }^{65}$ Idem.

${ }^{66}$ Idem.

${ }^{67}$ APEBA. Seção Colonial e Provincial. Série: Assuntos (escravos), maço 2896 (1870-1888).

${ }^{68}$ Idem.
} 
entrou o vigário em considerações sobre a escravidão, até que deixando-se levar, sem dúvida, pelo facto de estar sendo ouvido na maior parte por escravos, passou a gritar contra os senhores de escravos, contra a pessoa do Monarca e contra as autoridades, dizendo que estava em seu papel, que ninguém lhe faria calar-se. ${ }^{69}$ [grifos meus]

Diante daquilo que julgava representar um risco para a ordem social, o juiz imediatamente interrompeu o sermão do padre para advertir-lhe "pelo fato de pregar doutrinas sanguinárias aos seus ouvintes escravos, porquanto o lugar era impróprio". ${ }^{70}$ Como podemos perceber, a preocupação maior do juiz Municipal era o fato de o vigário pregar ideias tão radicais diretamente aos escravos, os quais compunham a maioria não só dos presentes à cerimônia religiosa como também das propriedades agrícolas da região.

Em resposta ao incidente, o presidente da província afirmou que tudo ficaria resolvido se as autoridades em questão circunscrevessem ao cumprimento de seus deveres. ${ }^{71}$ Mas, ao que tudo indica, o padre Geraldo Xavier de Santa'Anna não deu ouvidos ao juiz José Machado Pedreira nem ao presidente da província. Assim, ele não só continuou com as pregações abolicionistas como também atuou na denúncia de crimes cometidos contra os escravos, como o que vitimou fatalmente o "preto Claudemiro", escravo de José Fernandes de Castro e que estava alugado a Abílio José Ribeiro, português, de 27 anos, proprietário do sítio sugestivamente denominado de Mata-Negro, sito às margens do rio Mucuri. ${ }^{72}$

$\mathrm{O}$ inquérito para apurar a morte de Claudemiro foi feito em 11 de maio de 1887 por Martiniano Rodrigues da Fonseca, subdelegado de polícia do distrito dos Aymorés. A constatação dos maus tratos e dos excessivos castigos físicos que levaram o cativo a óbito foi confirmada por seis testemunhas. A primeira delas, Manoel Bahia, solteiro, de 30 anos, jornaleiro, natural da província de Minas, disse "que sendo trabalhador de Abílio José Ribeiro assistiu por diversas vezes o dito Abílio surrar o escravo Claudemiro”. Manoel Bahia inclusive foi um dos remadores da canoa que conduziu o cadáver do escravo para ser enterrado no povoado de Santa Clara e afirmou que na ocasião

viu os beiços do referido escravo arrebentados e muito inchados e chegando na ocasião de dar-se sepultura ao dito escravo o subdelegado de Santa Clara

\footnotetext{
${ }^{69}$ Idem.

${ }^{70}$ Idem.

${ }^{71}$ APEBA. Seção Colonial e Provincial. Série: Vigários. Maço 5231.

${ }^{72}$ APEBA. Seção Judiciária. Série: Homicídio. Class: 20/693/18. Réu: Abílio José Ribeiro X Vítima: Claudemiro escravo. Ano: 1887.
} 
Júlio Hansen e perguntando a Abílio o que era aquilo que ele viu nos beiços do dito escravo que estavam sobremodo arrebentados e inchados, respondeu que tinha sido uma queda que tinha tomado o escravo e o subdelegado satisfeito com esta resposta mandou enterrar o escravo. ${ }^{73}$

A testemunha contou ainda que "viu cicatrizes pelas costas e corpo do escravo, sendo umas novas e outras mais antigas, o que se reconhecia serem feitas por chicote, cujas surras, como já disse, assistiu o dito Abílio dar no escravo". Por fim, ao ser perguntado se o senhor era bom para os escravos, respondeu que "tem ouvido falar que Abílio é sobremodo desumano e carrasco para escravos, tanto quem tem escravos valentes e ruins manda para ele ensinar e amansar". ${ }^{74}$

Esta versão dos fatos também foi confirmada por Cesário Pinheiro, de 32 anos, viúvo, também natural da província de Minas, que contou

que foi trabalhador de Abílio um ano e meio mais ou menos e desde que chegou Claudemiro, escravo de José Padeiro, o dito Abílio o surrava desapiedosamente e não podendo continuar no sítio de Abílio em razão de não poder assistir ao martírio do dito escravo retirou-se para procurar serviço em outro lugar, e depois de sua saída soube pelos camaradas de Abílio que o escravo continuava sofrer continuadamente surras. ${ }^{75}$

Também presenciaram as surras e sem sucesso tentaram interceder a favor do escravo os jornaleiros Manoel Pinto Diniz, Antônio Pereira, José Barbosa e Florêncio Pereira de Figueiredo; todos ex-trabalhadores da propriedade do acusado. Aliás, a presença de vários indivíduos livres vendendo a sua força de trabalho aos proprietários da região indica que a transição para o trabalho livre estava adiantada na região e que otimizar a força de trabalho era primordial, ainda que para tal se lançasse mão do recurso à violência física.

Após concluir o inquérito, o subdelegado dos Aymorés enviou o caso diretamente ao juiz de Direito da comarca de Caravelas, o Dr. Luís Jacintho Vergne de Abreu. Porém, a este não cabia proceder a formação de culpa e por isso Vergne Abreu repassou o inquérito inicial para que o promotor público Francisco Antônio de Carvalhal oferecesse a denúncia ao juiz Municipal - o que só ocorreu em 06 de junho de 1887.

Assim, foi somente a partir do oferecimento da denúncia pelo promotor público que o juiz Municipal José Machado Pedreira entrou no caso. Esta inversão dos trâmites processuais, contudo, tinha a sua lógica. Na verdade, a

\footnotetext{
${ }^{73}$ Idem.

${ }^{74}$ Idem.

${ }^{75}$ Idem.
} 
aparente omissão do subdelegado do distrito dos Aymorés em não encaminhar o inquérito inicial diretamente para o juiz Municipal tinha por objetivo justamente evitar que este obstruísse a apuração do caso, arquivando a denúncia. Por detrás desta atitude, como veremos, estava o padre Geraldo Xavier de Sant'Anna.

Ao tomar conhecimento do ocorrido, o juiz Municipal logo fez ver em seu despacho que o inquérito não havia guardado as disposições legais. Ele também ressaltou que este "havia sido feito por autoridade incompetente, qual é o denunciado dos Aymorés tratando-se do denunciado que é fazendeiro nas margens do rio Mucury, que está sujeito à jurisdição da subdelegacia de Santa Clara", fato que segundo ele, "parece ter sido proposital como afronta a este juízo". Segundo Durval Vieira de Aguiar, no termo de Vila Viçosa realmente havia "lugares de jurisdição duvidosa, ou contestada, que são causas de conflitos de atribuições policiais, municipais ou fiscais". ${ }^{76}$ Mesmo assim, José Pedreira deu seguimento à formação de culpa, convocando as testemunhas indicadas para depor. E foi além. Diante das dificuldades na convocação destas, Pedreira deslocou-se até a povoação de Santa Clara e, no dia 04 de agosto de 1887, na presença do acusado e à revelia do promotor público, tomou alguns depoimentos.

Das seis testemunhas que haviam participado do inquérito inicial, duas não foram ouvidas. As demais, de forma surpreendente, mudaram radicalmente a versão dos fatos narrados anteriormente. O jornaleiro Antônio Pereira, por exemplo, que anteriormente havia partilhado das duras acusações a Abílio José Ribeiro, afirmou que "indo em dezembro do ano p.p. para a casa do acusado como empregado, já neste tempo lá encontrou o preto Claudemiro inchado e com febre", e que quando da sua morte este não tinha nenhum ferimento ou contusão. Perguntado sobre os castigos rigorosos que eram aplicados ao cativo, ele afirmou que "durante o tempo em que foi empregado do senhor Abílio viu-o apenas uma vez dar um bofetão no preto por ele ter furtado toucinho para comer assado tendo tomado remédio". ${ }^{77}$ Elogiando o tratamento que recebeu de Abílio Ribeiro enquanto foi seu empregado, Antônio Pereira disse que julgava o acusado "incapaz de praticar esse crime". Ao ser perguntado quem havia lhe interrogado nos Aimorés e por que haviam assinado o depoimento a rogo quando sabia assinar, Antônio Pereira respondeu que foi interrogado pelo "padre de Viçosa" e que não assinou seu depoimento porque "escreveram muita coisa que ele não disse".

\footnotetext{
${ }^{76}$ Ver AGUIAR, Durval Vieira de. Descrições práticas da Província da Bahia, 2a Ed., Rio de Janeiro, Cátedra; Brasília: INL, 1979, (1ª edição: Tipografia do Diário da Bahia, 1888), p. 293.

${ }^{77}$ APEBA. Seção Judiciária. Série: Homicídio. Class: 20/693/18. Réu: Abílio José Ribeiro X Vítima: Claudemiro escravo. Ano: 1887.
} 
De igual natureza foram as declarações de José Barbosa, que respondeu que foi depor não de "sua livre vontade, mas sim pela ameaça de prisão que lhe fez o vigário Geraldo de Viçosa". ${ }^{78}$ De um modo geral, agora, todos concordavam com a versão dada pelo réu de que o escravo falecera de febres e inflamações que sofria e que tudo não passava de uma intriga feita pelo padre Geraldo Xavier de Sant'Anna.

A oitiva das testemunhas arrastou-se por todo o ano de 1887 e mesmo já tendo colhido depoimentos suficientes para a conclusão da formação de culpa o caso só começou a ser definido quando o juiz Municipal José Pedreira e o promotor Carvalhal desocuparam seus cargos, fato que se deu respectivamente em julho de 1888 e maio de 1889.

Alegando falta de provas, visto que o exame de corpo de delito - peça essencial na composição da acusação - não havia sido feito, o novo promotor da comarca, José Franco de Lacerda, pediu o arquivamento da denúncia feita contra Abílio José Ribeiro, opinião que também foi partilhada pelo juiz Municipal Octaviano César Correia de Araújo, que ainda apontou muitas outras irregularidades no processo. Ao fazê-lo, obedecendo positivamente as regras processuais do direito, o novo juiz talvez não tivesse em mente o quanto aqueles erros ou omissões estavam atrelados a uma acirrada disputa em torno do direito de propriedade e o direito à liberdade. E assim, em 08 de janeiro de 1890, o parecer do juiz Municipal foi acatado pelo juiz de Direito, que deu o caso por encerrado.

A animosidade entre o padre Geraldo Xavier de Santa'Anna e o juiz municipal José Pedreira Machado prosseguiu até a decretação da abolição da escravidão e quiçá até depois desta. E se por um lado o vigário não conseguiu fazer das barras da justiça um caminho profícuo para a promoção das libertações dos escravos - como estava ocorrendo em outros cantos da província; de outro, suas pregações radicais aos cativos parecem ter surtido um efeito tão demolidor quanto o provocado pela moção de ações de liberdade. ${ }^{79}$ Seus discursos veementes e ousados potencializaram as ações de rebeldia dos escravos em toda a região, mesmo depois de realizada a abolição. Segundo Jaílton Lima Brito, ao tomar conhecimento da lei Áurea,

\footnotetext{
${ }^{78}$ Idem.

${ }^{79}$ No período compreendido entre 1884 e 1888 localizei apenas cinco ações de liberdade movidas nos termos de Viçosa e Porto Alegre, número considerado baixo se comparado às demais vilas da província baiana. Ver SILVA. Ricardo Tadeu Caires. Os escravos vão à Justiça: a resistência escrava através das ações de liberdade, Dissertação de Mestrado, UFBA, 2000, especialmente o capítulo 3.
} 
o padre Geraldo invadiu roças, mandando os escravos se reunirem na Fazenda Conquista, onde falou, para mais de quinhentos, que ele os havia libertado em nome de Jesus Cristo e que o Governo não se lembrava deles, pois estavam num local distante, e ameaço com o inferno aqueles que retornassem às fazendas. ${ }^{80}$

Assim, não só ali na Colônia Leopoldina, como em outras propriedades da região da comarca de Caravelas, os escravos, ao saberem que a abolição estava decretada, "convictos da palavra do padre, passaram a cobrar mil réis por dia para voltarem ao trabalho; outros abandonaram suas atividades, vagando pelas estradas embriagados e, nesse estado, insultavam os inimigos do padre e outros transeuntes". ${ }^{81}$ A desordem chegou a tamanha proporção que o chefe de Polícia da província teve de enviar reforços para a região. ${ }^{82}$

\section{Considerações finais}

Fundada nas primeiras décadas do oitocentos para ser uma colônia composta de famílias europeias, a Colônia Leopoldina logo se tornou um empreendimento escravista dirigida por proprietários estrangeiros e brasileiros interessados em alcançar a prosperidade econômica por meio da agricultura agroexportadora. Formada a partir da aquisição de escravos africanos nas décadas anteriores ao fim tráfico atlântico, a escravaria ali existente foi estimulada a se reproduzir endogenamente, de modo a suprir, de forma quase que autossuficiente, a necessidade de mais cativos trazidos de África-embora esses fossem vitais para a expansão dos negócios. Tal política, ao que parece, favoreceu a forte presença da família escrava entre os plantéis que compunham as mais de 50 fazendas destinadas ao cultivo do café.

Contudo, os desdobramentos da crise de mão de obra provocada pelo fim do tráfico de escravos, em 1850, fizeram com que as relações entre senhores e escravos ficassem cada vez mais tensionadas, sobretudo por conta da necessidade de aumento do ritmo de trabalho e das restrições na política de alforrias. ${ }^{83}$ Reagindo a estas transformações, os cativos da Colônia Leopoldina procuraram resistir às investidas senhoriais e assim garantir as condições que consideravam justas para suas vidas. ${ }^{84}$

\footnotetext{
${ }^{80}$ BRITO, op. cit., p. 269.

${ }^{81}$ Ibidem, p. 270.

${ }^{82}$ Sobre os conflitos que se seguiram à abolição ver, ainda, MATA, Iacy Maia. "Libertos de 13 de Maio" e ex-senhores na Bahia: conflitos no pós-abolição. In: Afro-Ásia, n. 35, 2007, pp. 163-198, 2007;

${ }^{83}$ Ver MARQUESE, Rafael de Bivar. "A dinâmica da escravidão no Brasil. Resistência, tráfico negreiro e alforrias, séculos XVII e a XIX”. Novos Estudos (74). Março, 2006, pp. 107-123.

${ }^{84}$ REIS, João José e SILVA. Eduardo. Negociação e conflito: a resistência negra no Brasil escravista. São Paulo: Companhia das Letras, 1989.
} 
O crescimento das ideias abolicionistas na região acirrou ainda mais os antagonismos de classe entre senhores e escravos. Tal reação resultou na eclosão de diversos conflitos, alguns dos quais acabaram em tragédias que, como vimos, vitimaram violentamente tanto os senhores quanto os escravos. Estes eventos, certamente contribuíram para acelerar a derrocada da escravidão na medida em que passaram a ameaçar a tranquilidade e a ordem social. ${ }^{85}$

E tranquilidade foi o que faltou naqueles agitados dias que precederam a abolição da escravatura no Brasil. Ocorrida sem a indenização da classe senhorial, a libertação imediata dos escravos do império, no dia 13 de maio de 1888, sinalizou também a morte da Colônia Leopoldina - ao menos nos moldes como a mesma funcionou por décadas a fio. Analisando o impacto da lei áurea na Bahia e, em especial na colônia, Arnold Wildberger concluiu que

os transtornos e prejuízos que este ato causa à lavoura do Recôncavo e do Sul
da Província são incalculáveis. Para Leopoldina representa este decreto o golpe
mortal; os emancipados abandonam as propriedades rurais; não aspiram outra
liberdade senão a do direito de viver nas cidades; vem a organização e a miséria.
As grandes e prósperas fazendas de café decaem rapidamente, os proprietários
que possuem recursos, repatriam-se, os menos aventurados emigram para as
cidades da Bahia e Rio de Janeiro, e a terra exuberante é abandonada por não
existirem braços para colherem os frutos. ${ }^{86}$

Muitos dos ex-cativos, contudo, permaneceram isolados no local formando assim o núcleo quilombola que até hoje habita o distrito de Helvécia, cujo nome deriva de uma das grandes propriedades que existiram nas imediações da Colônia Leopoldina e que simbolizava a origem suíça de grande parte de seus fundadores. ${ }^{87}$

Artigo recebido para publicação em 22/06/2016

Artigo aprovado para publicação em 29/06/2016

\footnotetext{
${ }^{85}$ Para outros casos de violência envolvendo o conflito de classe entre senhores e escravos na província da Bahia no período em tela ver FRAGA FILHO, op. cit., especialmente o capítulo 2.

${ }^{86}$ WILDBERGER, Arnold. Notícia Histórica de Wildberger \& Cia (1829-1942). Salvador, Ba: Tipografia beneditina, 1942, p. 87.

${ }^{87}$ Sobre a comunidade quilombola de Helvécia ver LUCCHESI, Dante; BAXTER, Alan; Ribeiro, Ilza (Orgs.). O português afro-brasileiro..., op. cit; SANTANA, Gean Paulo Gonçalves. Vozes e versos quilombolas: uma poética identitária e de resistência em Helvécia. Tese de Doutorado em Letras) - PUC-RS, Porto Alegre, 2014.
} 